\title{
Ecosystem services provided by the freshwater fauna of Madagascar's tropical rainforest: Case of the eastern coast (Andasibe) and the highlands (Antenina)
}

\begin{abstract}
This study contributes to relevant information on the value of biodiversity and aquatic ecosystems in the rainforest of Madagascar. Freshwater biodiversity provides multiple invaluable benefits to human life through their ecosystem services. This paper is a synthesis of two research studies. The first study took place at Andasibe rain forest in the eastern cost of Madagascar and the second research was in the Antenina forest which is a tropical rainforest located in the Highlands, in the Vakinankaratra region. Forests streams were characterized by the high diversity (Shannon Index: from 12 to 15). 66 taxa were identified in the eastern cost of Madagascar, and 46 taxa in the highlands area. So, freshwater fauna Predators are dominant like Odonata who contribute to the control of the density and dynamics of prey such as malaria mosquitoes. The filter feeders purify the water in the freshwater ecosystem while the collectors eat the organic particles in suspension. Therefore, they recover organic matter from erosion. Shredders and grazers feed on detritus and coarse particles. These feeding groups play important roles in the flow of matter and nutrients cycling and are part of the regulating and support ecosystem services. Aquatic organisms are mostly edible including freshwater fishes, crustaceans, crabs, shrimps and some families of insects such as the Oligoneuriidae of Ephemeroptera. In this sense, they provide procurement services. Both rain forest protected park in the eastern cost and the highlands provide a socio-cultural service as it serves as a recreation area and cultural identity for the local population.
\end{abstract}

Volume 5 Issue I - 202 I

\author{
Ranalison Oliarinony,' Ravakiniaina \\ Rambeloson,' Danielle Aurore Doll Rakoto \\ 'Zooogy and Animal Biodiversity, University of Antananarivo, \\ Madagascar \\ ${ }^{2}$ Fundamental and applied biochemistry Department, University \\ of Antananarivo, Madagascar
}

\section{Correspondence: Ranalison Oliarinony, Zoology and \\ Animal Biodiversity, University of Antananarivo, Antananarivo, Madagascar, Tel +26I(0)330I 466 87,}

Email ranalison.oliarinony@gmail.com

Received: April 28, 2021 | Published: June 21, 2021

\section{Introduction}

Considering the rapid change in ecosystems over the past half century, ecosystem services have gained prominence since humanity owes everything to sustainable and good quality ecosystems. The notion of ecosystem services has become popular after the publication of the Millennium Ecosystem Assessment report in 2005. Ecosystem services are defined as the benefits that humans derive from ecosystems. ${ }^{1}$ In Madagascar, the adoption of the concept of ecosystem services is taking place in several stages. (1) in the late 1990s: exploratory thinking on the total value of forest products; (2) in 2000-2004: advanced thinking with economists' studies devoted to sustainable financing and the extension of the protected area network; (3) since 2004: implementation of project schemes valuing ecosystem services, including carbon sequestration, hydrological services, and biodiversity conservation. ${ }^{2}$

Implementing ecosystem services means better ecosystem management on the one hand, and better protection of biodiversity on the other. According to the Millennium Ecosystem Assessment report in 2005, ecosystem services have been classified into 4 categories: (i) supporting or sustaining services, (ii) regulating services, (iii) provisioning or productive services, (iv) Tropical forests, especially rainforests, are the most productive and biodiverse ecosystems. In addition, tropical forests play a critical role in the water cycle. ${ }^{3}$ Rain tropical forest perform important regulating services.
They play an important role in regulating the global climate through carbon sequestration. ${ }^{4}$ The aim of this study is to (i) analyze the effect of deforestation by comparing the abundance and diversity of the forest population versus the population in the degraded area. (ii) To identify existing ecosystem services of freshwater fauna while taking into consideration feeding group.

\section{Materials and methods}

For the first investigation, detailed informations are described in previous study. ${ }^{5}$ Three staggered campaigns were carried out (June, September and late November 2001). The study took place at Andasibe-Mantadia's area in five draining protected rain forest within Andasibe National Park, in eastern Madagascar and five savoka streams draining the park's largely deforested peripheral zone. Savoka is characterized by secondary vegetation. The stations are located at an average altitude of 710 to $950 \mathrm{~m}$ and the geographical coordinates vary from $18^{\circ} 48^{\prime} 56^{\prime \prime} \mathrm{E}$ to $48^{\circ} 22^{\prime} 47^{\prime}$ 'S. As for the second investigation, the sampling was carried out during ten days in September 2011. Six stations including three in the open canopy environment and three in the closed canopy environment, were selected. The study area is in the Antenina forest which is a tropical rainforest located in the Highlands, in the Vakinankaratra region. The stations are located between $19^{\circ} 43^{\prime} 56^{\prime \prime} \mathrm{S}$ and $47^{\circ} 49^{\prime} 51^{\prime \prime} \mathrm{E}$ with $1350 \mathrm{~m}$ altitude. The fauna such as freshwater insects, molluscs, crustaceans, crabs and shrimps are collected by Surber net, but fishes were caught with a hawk net. The 
diversity is highlighted by the Shannon-Weaver index. The feeding groups are determined by the following references: ${ }^{6-9}$

\section{Results}

The first table includes the following the number of individuals captured, abundance and diversity of freshwater fauna sampled. The second table concerns the list of freshwater fauna sampled according the feeding group and the endemics species or genus are indicated by the abbreviation (E).

Among the 66 taxa, aquatic insects are the most abundant, amounting to $98 \%$ of the individuals sampled, the remaining $2 \%$ are Crustacea and Crayfish, Planaria, Molluscs and Annelids. The Baetidae (Ephemeroptera) are dominant and represent 21\% of the captured Macroinvertebrates, then the Orthocladinae (Diptera) 17\%, the Simuliidae (Diptera) with $15 \%$ and finally the Hydropsychidae (Trichoptera) with about 7\%. Among 50 taxa, four taxa are fishes, 46 taxa are freshwater invertebrates. From $37 \%$ to $63 \%$ of the sampled fauna are Trichoptera. From $22 \%$ to $40 \%$ are Coleoptera.

Feeding method, (E): Endemicity Although most of the taxa are identified at the higher rank, i.e. at the family and genus level, the results obtained reflect the riches and the high endemicity of Madagascar's rain forest freshwater fauna. For example, the Ephemeroptera, nine families among the eleven existing families in Madagascar, are sheltered in this type of forest. Still in this order Ephemeroptera, but at the level of the family Tricorythidae, three genera are endemics (Madecassorythus, Ranorythus and Spinirythus), the only genus Tricorythus is cosmopolitan among the four genera constituting this family.

All the different trophic groups are represented. The dominance of predatory organisms is well marked. This type of interaction is mostly beneficial because we have seen the presence of mosquitoes (Culicidae, Anopheles), vector of paludismin our study area. Odonata participate in the control of the density and the ecological balance of the population dynamics of this Diptera by predation. The filter feeders are composed of all the genera of the family Tricorythidae (Ephemeroptera), Oligoneuriidae (Ephemeroptera), Hydropsychidae (Trichoptera), Philopotamidae (Trichoptera) and Simuliidae (Diptera). These freshwater animals are equipped with specialized organs for water filtration to recover food particles. Therefore, they contribute to the purification of water. The Tricorythidae family has long bristles on the mouth parts. The Oligoneuriidae are distinguished by the labium of their mouth parts which take the shape of a sickle, covered with numerous setae. The two families of Trichoptera and the nymph of Simuliidae are provided with sheaths through which water circulates. Aquatic insects filter water through their sheaths. These filter feeders are found in the forest area because they need fresh and well oxygenated water. Collectors collect suspended fine particulate organic matter and recover inorganic material from erosion. Grazers are more abundant than shredders because they exploit the particles already shredded by the shredders. Since the role of shredders is to crush and chop up coarse organic material such as shredded foliage, stems and dead wood that have become detritus, the scarcity of shredders may reflect the existence of disturbance to riparian vegetation, including the destruction of the forest in its watershed.

\section{Discussions and conclusion}

The taxonomic richness of the Andasibe forest (eastern cost) is higher ( 66 taxa) than that of Antenina (50 taxa). This can be explained by the high number of sampling stations ( 10 stations versus 6 stations). It is the same for the Shannon index (15 versus 12) and the number of individuals collected (25 700 versus 1530 ). In the Andasibe forest, the diversity of the forest population (Shannon index $=15$ ) is higher than that of the population in the degraded area (12). This is not the case for the Antenina forest, the difference in forest fauna diversity (12) is small compared to that of the open canopy area (11). As Andasibe is a protected area, the freshwater forest population benefits from the protection of the ecosystem, but in Antenina, human frequentation is intensive. Local people use the forest trees for firewood. In this study area, there is illegal gold mining. It has a negative impact on river ecosystem and biodiversity. It not only destroys the forest and the physical characteristics of the river (e.g. turbidity, water flow velocity) but also it deteriorates the water quality leading to water pollution. ${ }^{10}$

Freshwater fauna, especially Macro invertebrates are good bio indicators and have been used in several countries for many years. ${ }^{11}$ In our case, they are indicators of deforestation. The humid tropical fauna of Madagascar (Andasibe and Antenina) hosts several endemic species. We have seen that all the genera of Tricorythidae (Ephemeroptera) are met in our study area with clearly elevated endemicity. All species (four species) of the genus Madecassorythus are endemic. ${ }^{12,13}$ Similarly, all species (two) of Ranorythus ${ }^{14}$ all species (three) of Spinirythus ${ }^{15}$ and nine species of Tricorythus ${ }^{15}$ are endemic to Madagascar. This family is a good tool for cladistic analysis and the study of the biogeography of the tricorythid Afrotropical fauna. ${ }^{16}$ Based on feeding group, shredders are detritivores that feed on coarse fractions of dead leaves. Grazzers are herbivores that eat algae attached to the substrate associated with organic or mineral matter and collectors that feed on fine particles deposited on the substrates. These organisms are the prey of predators which are either insects or fishes and the final consumer is mankind. So, freshwater fauna are useful not only for its participation in the flow and cycle of matter, but also to reduce the products of erosion which harm the health of the river hydro system. Therefore, they contribute to the support service.

Regulating services are the non-material benefits provided by the proper functioning of ecosystems.

Filtering organisms play an important role in water purification; these organisms contribute to the regulatory service of water de pollution. Predators contribute to the reduction of insect pests. They also attack the immature stages (eggs and larvae) of invasive species. ${ }^{17}$ In fact, they control the spread of invasive species. So, their role is part of the regulatory service. The aquatic ecosystem plays the role of water reservoir and storage during the flood period, especially the one in the forest area that prevents flooding. This is the water regulation service. Ephemeroptera community composition changes in response to changes in various environmental variables. ${ }^{18}$ They have the potential to be employed the development of biotic insects to monitor agricultural practices. ${ }^{19}$ The order ephemeroptera is useful forhuman health. Ephemeroptera cuticles are evaluated as a source of chitin which was transformed into Chitosan. Ephemeroptera chitosans are shown to have strong inhibitory activity on cancer cells. ${ }^{20}$ Elassoneuria larvae of the Olgoneuriidae (Ephemeroptera) have been sold as "Mangoro River shrimp" in the eastern coast of Madagascar (Comm. Pers); human consumption of mayflies has been observed in ten countries. ${ }^{21}$ These insects are rich in proteins, minerals, B vitamins, essential amino acids and low in fat. ${ }^{22}$ Species of four families of fishes collected and species of Decapoda are valued as sources of protein and used as food sources for humans. These animals serve the supply service. As already mentioned, predators play a role in regulating the density of prey such as Odonata that which eat mosquitoes. This order of insects provides an indirect service that is indicative of climate change because $4^{\circ} \mathrm{C}$ warming in larval stage if damselfy 
Ischnura elegans decreased the flight muscle mass and a lower fligth endurance..$^{23}$ Ephemeroptera provides a socio-cultural service as some companies use this order in the marketing field. Nike introduced a line of ultra light running shoes called "Mayfly" in $2003 .{ }^{24}$

The protected area of the humid tropical forest of Andasibe and the humid forest of Antenina attract many tourists and researchers (Comm. Pers). They are recreational and educational areas. Walking in the forest maintains good mental health. The biodiversity inside the forest provides inspiration for artists and designers. The rainforest of Madagascar provides socio-cultural service.

\section{Acknowledgments}

None.

\section{Conflicts of interest}

The authors declare no conflicts of interest.

\section{References}

1. BruijnzeelL.Hydrological functions of tropical forests. notseeing the soil for the trees? Agriculture, Ecosystems and Environment.2004;104:185-228.

2. Andriamahefazafy F, Bidaud C, Méral P, et al. L'introduction de la notion de service environnemental et écosystémique à Madagascar. VertigO. 2012;12(3).

3. United Nations. Clean water and sanitation. Sustainable Development Goals. 2019.

4. Watson RT, Noble IR, Bolin B, etal.IPCCspecialreporton land use, landuse change and forestry. Cambridge University Press, Cambridge, UK. 2000.

5. Oliarinony R. Influences de la déforestation sur la structure des macroinvertébrés aquatiques dans la région d'Alaotra Mangoro. Cas des Insectes aquatiques : Ephéméroptères. Thèse de Doctorat. Université d'Antananarivo. Madagascar.2010.

6. Dudgeon D. Patterns of variation in secondary production in a tropical stream hydrobiology. 1999;144(3):271-281.

7. Benstead PJ, Pringle CM. Deforestation alters the resource base and biomass of endemic stream insects in eastern Madagascar. Freshw Biol. 2004;49(4):490-501.

8. Palmer C, O'Keeffe J, Palmer A, et al. Macroinvertebrate functional feeding groups in the middle and the lower reaches of the Buffalo River, Eastern Cape, South Africa I Dietary variability. Freshwater Biology.1993;29:441-453.

9. Gattolliat JL, Sartori M. An overview of the Baetidae of Madagascar. University of Perugia. Perugia Italy. 2003;135-144.

10. Rahm BG, Riha SJ. 2012. Toward strategic management of shale gas development. regional, collective impacts on water resources. Environmental Science \& Policy. 2012;17:12-23.
11. RoyAH, Rosemond MJ, Paul MJ, et al. Stream macro invertebrate response to catchment urbanization. Freshwater Biology.2003;48:329-346.

12. Elouard JM, Oliarinony R. Biodiversité aquatique de Madagascar 6 Madecassorythus un nouveau genre de Tricorythidae définissant la nouvelle sous familledes Madecassorythinae (Ephemeroptera, Pannota). Bulletin de la Société entomologiquede France. 1997a;102(3):225-232.

13. Oliarinony R, Sartori M, Elouard JM. Première description des larves et des œufs du genre malgache Madecassorythus (Ephemeroptera, Tricorythidae). Mitteilungen der Scweizerischen Entomologischen Gesellschaft. 2000;73:369-378.

14. Oliarinony R, Elouard JM. Biodiversité aquatique de Madagascar 7. Ranorythus un nouveau genre de Tricorythidae définissant la nouvelle sous famille des Ranorythinae (Ephemeroptera, Pannota). Bulletin de la Société entomologique de France. 1997b;102(5):439-447.

15. Oliarinony R, Elouard JM, Raberiaka N. Biodiversité aquatique de Madagascar 8 Spinirythus un nouveau genre de Tricorythidae (Ephemeroptera, Pannota). Bulletin de la Société entomologique de France. 1998;103(5):237-244.

16. Barber James HM. A synopsis of the Afrotropical Tricorythidae. In Hauer FRJA. Stanford and RL Newell edn. International Advances in the Ecology. Zoogeography and Systematics of Mayflies and Stoneflies. University of California Press. Entomology. 2008;128:187-203.

17. Oliarinony R, Randriamanantsoa M, Rasoamampionona N, et al. Bioécologie de l'écrevisse envahissante Procambarus sp (Decapoda, Cambaridae)à Madagascar. Acte du Colloque Régional sur les espèces exotiques envahissantes des îles du sud ouest de l'Océan Indien. 2014;271-283.

18. Zedkova B, Radkova V, Bojkova, et al. Mayflies (Ephemeroptera) as indicators of environmental changes in the past five decades: A case study from the Morava and Odra River Basins (Czech Republic). Aquat. Conserv Mar.Freshw. Ecosyst. 2015;25:622-638.

19. Svensson A, Bellamy AS, Van den Brinck PJ, et al. Assessing the ecological impact of banana farms on water quality using aquatic macroinvertebrate community composition. Environ Sci Pollut Res. 2018;25:13373-13381.

20. Tan G, Kaya M, Tevlek A, et al. Antitumor activity of chitosan from mayfly with comparison to commercially available low, medium and high molecular weight chitosans. Invitro Cell Dev Biol Anim. 2018;54(5):366374.

21. Macadam CR, Stockan JA. The diversity of aquatic insects used as human food. J Insects Food Feed. 2017;3(3):203-209.

22. Bergen WG, Busboom J, Merkel RA. Leucine degradation in sheep. Br J Nutr. 1988;59:323-333.

23. Tuzun N,Op de Beeck L, Oliarinony R. Warming under semi natural outdoor conditions in the larval stage negatively affects insect flight performance. Biology Letters. 2018;14(5).

24. Jacobus LM, Macadam CR, Sartori M. Mayflies (Ephemeroptera) and Their Contributions to Ecosystem Services. Insects. 2019;10(6):170. 